\title{
Endemic Goitre in Greece: A Study of 379 Twin Pairs
}

\author{
B. MALAMOS, D. A. KOUTRAS, P. KOSTAMIS, G. A. RIGOPOULOS, N. S. ZEREFOS, \\ and $\mathrm{X}$. A. YATAGANAS
}

From the Department of Clinical Therapeutics, "Alexandra" Hospital, University of Athens, Greece

Non-toxic goitre is endemic in Greece (Malamos Koutras, Kostamis, Kralios, Rigopoulos, and Zerefos, I966a), and detailed biochemical studies have implicated iodine deficiency as the main causative factor (Malamos, Miras, Koutras, Kostamis, Binopoulos, Mantzos, Levis, Rigopoulos, Zerefos, and Tassopoulos, I966b). However, in the endemic regions studied, both goitrous and non-goitrous persons are iodine deficient practically to the same extent (Malamos et al., 1966b), which agrees with results in other parts of the world (Wayne, Koutras, and Alexander, 1964), most notably in Western New Guinea (Choufoer, van Rhijn, Kassenaar, and Querido, 1963). This has prompted a search for additional factors which predispose a part of the population to goitre development, or to put it in another way, which protect the other from it.

It is now recognized that some cases of sporadic goitre, with or without cretinism, are due not to iodine deficiency but to inherited defects in the biosynthesis of thyroid hormones (McGirr, I960; Stanbury, I966; Wayne et al., 1964). None of these defects has been proved to occur in endemic goitre (Murray and Stanbury, 1962), and a careful search in Greece has not produced evidence that any of these is of importance in the aetiology of the goitrous endemic (Malamos et al., 1966b). Nevertheless, since the environmental factor of iodine deficiency does not explain entirely the development of endemic goitre, this has revived interest in the possible implication of genetic factors, which may potentiate the effects of a mild environmental iodine deficiency. Hadjidakis, Koutras, and Daikos (1964) have shown that in Greece endemic goitre affects some families more than others from the same village. This has been interpreted as

\footnotetext{
Received May 2, 1966.

* This study was supported by Grants No. AM 07464-02 and I Ror AM 08987- IA I from the National Institutes of Health, Public Health Service, Bethesda, Md, U.S.A.
}

evidence of an inherited factor, though the influence्ढ of the small family environment cannot be excludedic

In a subsequent study by Malamos et al. (1966a) the familial aggregation of goitrous cases has been $\rho$ confirmed. However, it has been found that not only are the progeny of goitrous persons more extensively affected than the descendants of nongoitrous parents, but also that there is a statisticallys significant concordance between husbands and wives. Women married to goitrous men are़ themselves more often goitrous than the wives of the non-goitrous inhabitants of the same village? This, of course, points to the small family environ ment rather than to heredity as the cause of the familial aggregation of cases.

In view of these inconclusive findings, the presento investigation was undertaken. 379 twin pairs? from the endemic regions of central Greece were 3 examined for the presence or absence of goitre, and the results were analysed separately for the monozygotic and the dizygotic twins, in order to find out whether there was a higher concordanceo in the former, as would be expected if goitre was an? inheritable characteristic.

\section{Subjects and Methods}

Visits were made to rog goitrous villages in three? administrative districts (Table I). A sample of the population (usually children and adolescents aged 10-20․ years) was examined for goitre, in order to know then over-all prevalence in these regions. All the twins

TABLE I

\begin{tabular}{|c|c|c|c|}
\hline & \multicolumn{3}{|c|}{ Administrative District } \\
\hline & Eurytania & Larissa & Jannina \\
\hline $\begin{array}{l}\text { Goitrous villages studied } \\
\text { Population } \\
\text { Number of persons examined } \\
\text { Percentage of persons with } \\
\text { goitre } \\
\text { Twin pairs }\end{array}$ & $\begin{array}{l}23 \\
15,614 \\
404 \\
54 \cdot 5 \\
51\end{array}$ & $\begin{array}{c}46 \\
60,488 \\
2452 \\
50 \cdot 8 \\
172\end{array}$ & $\begin{array}{l}40 \\
33,713 \\
2159 \\
52 \cdot 6 \\
156\end{array}$ \\
\hline
\end{tabular}


living in these villages were examined clinically for the presence or absence of goitre, by the criteria previously used by us (Malamos et al., 1966a). If one of the twins was not living in the village, the pair was excluded from the study.

The twin pairs were classified as monozygotic or dizygotic, on the basis of the general appearance and the following blood tests, which were performed at the Haematology Laboratory of the 'Alexandra' Hospital (Dr. Ph. Fessas): (I) ABO, (2) CDE, and (3) M, N.

\section{Results}

The general characteristics of the population investigated are shown in Table I. Table II summarizes the results, the statistical analysis of which is shown in Table III.

It is obvious from Table II that the group of dizygotic twins contains a higher proportion of discordant pairs (i.e. the one twin goitrous and the other non-goitrous) than the monozygotics, which are to a greater extent concordant (i.e. either both members of the pair goitrous or both non-goitrous).

TABLE II

RESULTS OF TWIN PAIRS EXAMINATION

\begin{tabular}{|c|c|c|c|}
\hline & & Number & Percentage \\
\hline Monozygotic males & $\left\{\begin{array}{l}\text { Both goitrous } \\
\text { Neither goitrous } \\
\text { Discordant }\end{array}\right.$ & $\begin{array}{r}9 \\
39 \\
6\end{array}$ & $\begin{array}{l}16 \cdot 7 \\
72 \cdot 2 \\
11 \cdot 1\end{array}$ \\
\hline Monozygotic females & $\left\{\begin{array}{l}\text { Both goitrous } \\
\text { Neither goitrous } \\
\text { Discordant }\end{array}\right.$ & $\begin{array}{r}16 \\
20 \\
4\end{array}$ & $\begin{array}{l}40.0 \\
50.0 \\
10.0\end{array}$ \\
\hline Dizygotic males & $\left\{\begin{array}{l}\text { Both goitrous } \\
\text { Neither goitrous } \\
\text { Discordant }\end{array}\right.$ & $\begin{array}{l}13 \\
42 \\
16\end{array}$ & $\begin{array}{l}18 \cdot 3 \\
59 \cdot 2 \\
22 \cdot 5\end{array}$ \\
\hline Dizygotic females & $\left\{\begin{array}{l}\text { Both goitrous } \\
\text { Neither goitrous } \\
\text { Discordant }\end{array}\right.$ & $\begin{array}{l}17 \\
30 \\
21\end{array}$ & $\begin{array}{l}25 \cdot 0 \\
44 \cdot 1 \\
30 \cdot 9\end{array}$ \\
\hline $\begin{array}{l}\text { Dizygotic male and } \\
\text { female }\end{array}$ & $\left\{\begin{array}{l}\text { Both goitrous } \\
\text { Neither goitrous } \\
\text { Male goitrous } \\
\text { Female goitrous }\end{array}\right.$ & $\begin{array}{r}25 \\
72 \\
4 \\
45\end{array}$ & $\begin{array}{r}17 \cdot 1 \\
49 \cdot 4 \\
2 \cdot 7 \\
30 \cdot 8\end{array}$ \\
\hline
\end{tabular}

TABLE III

STATISTICAL ANALYSIS

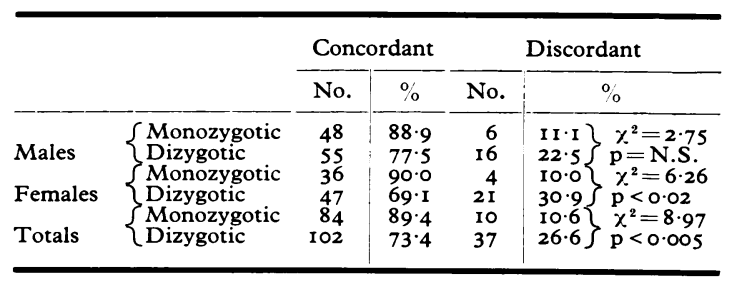

N.S. is not significant.
However, in Greece there is a sex difference in the prevalence of endemic goitre (Hadjidakis et al., 1964; Malamos et al., I966a), and for this reason dizygotic pairs of different sex have been excluded from the statistical analysis shown in Table III. This compares the results obtained in monozygotic twins with those obtained with dizygotic twins concordant as to sex, i.e. either both members of the twin pair males or both females, pairs consisting of one male and one female twin being excluded. Even so there is a difference in the concordance rate between monozygotic and dizygotic twins. This difference is statistically significant for female twins $\left(\chi^{2}=6.26, p<0.02\right)$ or for both sexes taken together $\left(\chi^{2}=8.97, \mathrm{p}<0.005\right)$. For male twins there is only a suggestive trend $\left(\chi^{2}=2.75\right.$, $0.05<\mathrm{p}<0.10$ ).

If the concordant twin pairs are subdivided into those with both members goitrous and those with neither, the results are similar $\left(\chi^{2}\right.$ with two degrees of freedom: for males $3.08,0.20<p<0.30$; for females 6.85, $\mathrm{p}<0.05$; for both sexes 8.97, $\mathrm{p}<$ $0.02)$.

\section{Discussion}

It is clear from the results presented above that monozygotic twins have a higher rate of concordance for the presence of endemic goitre than dizygotic twins. Twins of the same sex, either mono- or dizygotic, are supposed to share the same small family environment, and so the increased concordance is attributed to the greater genetic similarity characterizing the monozygotic twins. In fact this problem may be more complicated, since monozygotic twins may have a more similar environment than dizygotic ones. Nevertheless, the environmental factors leading to goitre are mainly dietetic ones, and twins either mono- or dizygotic presumably share the same food.

The decision whether twins are identical (monozygotic) or not is often very difficult, requiring examination of the placenta and complete blood group studies (Clarke, 1964). However, in a study of a large number of twin pairs such as this, an occasional error in classification would not be expected to alter appreciably the over-all results, and for this reason the criteria for monozygosity adopted here (general appearance and a limited number of blood tests) appear adequate.

The results of this study do not conform to those previously obtained from Switzerland by Eugster (1934), who reported that monozygotic twins did not show a greater concordance with respect to endemic goitre than did dizygotic ones. The reason for this discrepancy may be that in Switzer- 
land the environmental factor (iodine deficiency) has been stronger than it is now in Greece, thus masking the possible contribution made by heredity, or that in Switzerland the population is genetically more homogeneous for the characteristics predisposing to goitre. Furthermore, endemic goitre should not be viewed as a single entity. Although iodine deficiency is generally accepted as the decisive factor in most endemics (Wayne et al., 1964), nevertheless the dietary iodine intake and the urinary excretion values range from a few $\mu \mathrm{g}$. per day, as in New Guinea (Choufoer et al., I963), to levels generally considered as adequate, as in Eastern Kentucky (London, Koutras, Pressman, and Vought, 1965). In this latter case factors other than iodine deficiency are presumably involved, but their nature remains still elusive.

Taste sensitivity to phenylthiourea (PTC) has not been studied in the present work, since in Greece there is no relation between PTC taste sensitivity and endemic goitre (Malamos et al., 1966a). An association between the non-taster status and sporadic non-toxic goitre has been previously reported by some workers (Harris, Kalmus, and Trotter, I949; Kitchin, HowelEvans, Clarke, McConnell, and Sheppard, 1959) but denied by Fraser (1963). In endemic goitre in Israel an association has been reported by Brand (I963), but in other countries this has not been the case (Fraser, 1963; De Luca and Cramarossa, 1965; Malamos et al., I966a).

The evidence from the present study, as stated above, points to heredity as playing a role in the familial association of goitrous cases previously reported by several authors (Trotter, Cochrane, Benjamin, Miall, and Exley, 1962; Hadjidakis et al., 1964; London et al., 1965; Malamos et al., 1966a). It would be difficult, however, to define more precisely the nature of the genetic factors involved and how they affect the predisposition to endemic goitre. A frequency distribution diagram of the estimated thyroid gland sizes in the endemic areas of Greece does not show two peaks, but only a continuous unimodal curve (Malamos et al., I966a), thus excluding any simple mode of inheritance. Environmental factors such as iodine deficiency are more important than heredity, since, in order to prove a statistical difference no less than 379 twin pairs have been required in the present study, whereas if heredity was a more important factor there would be a more striking difference between mono- and dizygotic twins, readily recognizable even in a much smaller population sample. So it may be concluded that, though heredity seems to be indeed implicated in the predisposition to endemic goitre, its role is probably a minor one, in compard son with the potent environmental factors involved?

\section{Summary}

In 109 villages in the endemic goitre areas of Greece 379 twin pairs were examined for th presence or not of goitre. There was a highe concordance rate between the members of the monozygotic twin pairs than in the dizygotic oness? The difference was statistically significant even dizygotic twins of different sex were excluded. It is concluded that heredity plays a role, probably a minor one, in the predisposition to endemis goitre.

We wish to thank Dr. C. B. Krimbas, Professor $\vec{f}$ Genetics at the Athens College of Agriculture, for hP valuable advice for the completion of this study, and Drs. E. Mavroulidis and B. Papadakos, of the Depart ment of Health, and the District Health Officers, $\mathbf{S}$ Zannias of Eurytania, L. Strakalis of Larissa, and Economopoulos of Jannina, for their helpful assistance

\section{REFERENCES}

Brand, N. (I963). Taste sensitivity and endemic goitre in Israet Ann. hum. Genet., 26, 321.

Choufoer, J. C., van Rhijn, M., Kassenaar, A. A. H., and Querido, (I963). Endemic goiter in Western New Guinea: iodine metabo lism in goitrous and nongoitrous subjects. $\mathcal{F}$. clin. Endocr., 2, 1203

Clarke, C. A. (1964). Genetics for the Clinician, and ed. Blackwe Oxford.

De Luca, F., and Cramarossa, L. (1965). Phenylthioruea and endemic goitre. Lancet, I, 1399.

Eugster, J. (1934). Zur Erblichkeitsfrage der endemischen Struma Arch. Klaus-Stift. Vererb.-Forsch., 9, 275.

Fraser, G. R. (1963). A genetical study of goitre. Ann. hum. Genet. 26, 335 .

Hadjidakis, S. G., Koutras, D. A., and Daikos, G. K. (1964) Endemic goitre in Greece: family studies. F. med. Genet., 1, 82 .

Harris, H., Kalmus, H., and Trotter, W. R. (1949). Taste sens? tivity to phenylthiourea in goitre and diabetes. Lancet, 2, 1038. Kitchin, F. D., Howel-Evans, W., Clarke, C. A., McConnell, R. Bं and Sheppard, P. M. (1959). P.T.C. taste response and thyroig disease. Brit. med. F., I, 1069.

London, W. T., Koutras, D. A., Pressman, A., and Vought, R. I (1965). Epidemiologic and metabolic studies of a goiter endemie

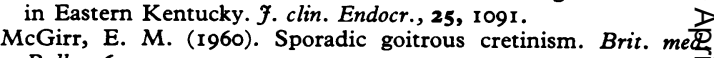
Bull., 16, I 13.

Malamos, B., Koutras, D. A., Kostamis, P., Kralios, A. C., Rigo poulos, G., and Zerefos, N. (1966a). Endemic goiter in Greece: epidemiologic and genetic studies. F. clin. Endocr. 26, 688.

, Miras, K., Koutras, D. A., Kostamis, P., Binopoulos, D Mantzos, J., Levis, G., Rigopoulos, G., Zerefos, N., and Taś sopoulos, C. N. (1966b). Endemic goiter in Greece: metabold studies. ibid., 26, 696.

Murray, I. P. C., and Stanbury, J. B. (1962). Endemic goiter. fo

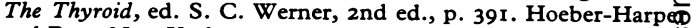
and Row, New York.

Stanbury, J. B. (1966). Familial goiter. In The Metabolic Basis of Inherited Disease, ed. J. B. Stanbury, J. B. Wyngaarden, anf D. S. Fredrickson, 2nd ed, p. 215 . McGraw-Hill, New York. O Trotter, W. R., Cochrane, A. L., Benjamin, I. T., Miall, W. E., ang Exley, D. (1962). A goitre survey in the Vale of Glamorgar Brit. F. prev. soc. Med., 16, I6.

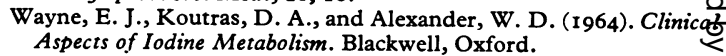

